\title{
PENDAYAGUNAAN WAKAF DI TENGAH PANDEMI COVID-19 DALAM PERSPEKTIF MAQASHID AL-SYARIAH
}

\section{Miftakhuddin*, Khofifah Trisnah Lestari, Aniroh Aniroh,} Hendri Hermawan Adinugraha

Institut Agama Islam Negeri (IAIN) Pekalongan, Indonesia

mmiftakhuddin@mhs.iainpekalongan.ac.id, khofifahtrisnahlestari@gmail.com, aniroh_aniroh@yahoo.com, hendri.hermawan@iainpekalongan.ac.id

https://doi.org/10.46367/iqtishaduna.v10i1.313

Received: Apr 09, 2021 Revised: Jun 01, 2021 Accepted: Jun 12, 2021 Published: Jun 29, 2021

\begin{abstract}
The use of waqf instruments to overcome social and economic problems should also provide opportunities for handling the Covid-19 pandemic that is currently hitting the world. Handling a pandemic requires clear and strategic objectives, as stated in the maqashid sharia concept. This paper aims to analyze the use of waqf in the midst of the Covid-19 pandemic and its suitability with the perspective of maqashid sharia. The method used in this research is a qualitative method with an analysis-descriptive approach from a literature study. The results showed that in Indonesia, the use of waqf to overcome the problem of the Covid-19 pandemic is still not optimal, but waqf has great potential in providing hospitals and other health facilities. In the perspective of maqashid sharia, the utilization of waqf is also in accordance with the description of three concepts of needs according to As-Syatibi, namely dharuriyah, hajiyah, and tahsiniyah.
\end{abstract}

Keywords: Empowerment of Waqf, Maqashid Sharia, Covid-19.

\begin{abstract}
ABSTRAK
Penggunaan instrumen wakaf untuk mengatasi persoalan sosial dan ekonomi, seharusnya juga dapat memberikan peluang untuk penanganan pandemi covid-19 yang melanda dunia pada saat ini. Penanganan pandemi membutuhkan tujuan yang strategis dan jelas, sebagaimana tertuang dalam konsep maqashid syariah. Tulisan ini bertujuan untuk menganalisis pendayagunaan wakaf di tengah pandemi Covid-19 serta kesesuaiannya dengan perspektif maqashid syariah. Metode yang digunakan dalam penelitian ini adalah metode kualitatif dengan pendekatan analisis-deskriptif dari studi kepustakaan. Hasil penelitian menunjukkan bahwa di Indonesia pendayagunaan wakaf untuk mengatasi permasalahan pandemi covid-19 masih belum optimal, akan tetapi wakaf berpotensi besar dalam menyediakan rumah sakit dan fasilitas kesehatan lain. Dalam perspektif maqashid syariah, pendayagunaan wakaf juga sudah sesuai dengan penjabaran tiga konsep kebutuhan menurut As-Syatibi yaitu dharuriyah, hajiyah dan tahsiniyah.
\end{abstract}

Kata Kunci: Pendayagunaan Wakaf, Maqashid Al-Syariah, Covid-19. 


\section{PENDAHULUAN}

Hampir seluruh negara yang ada di dunia terdampak oleh pandemi covid19. Penyebaran virus ini sangat cepat, dimana awal kemunculan kasusnya bermula dari negara China, dan sekarang sudah menyebar hampir ke seluruh negara di dunia. Banyak negara yang mengalami situasi panic atau kewaspadaan tingkat tinggi dalam memutus rantai penyebaran covid-19, hal ini dilakukan agar virus tidak menyebar semakin luas. Indonesia sendiri dalam situasi pandemi menerapkan aturan social distancing bahkan dengan skala yang besar atau yang lebih dikenal dengan pembatasan sosial berskala besar (PSBB).

Aturan PSBB banyak membuat aktivitas masyarakat berkurang bahkan cenderung terhenti. Banyak industri besar yang melakukan pemutusan hubungan kerja (PHK) kepada karyawannya, usaha mikro, kecil dan menengah (UMKM) banyak yang mangkrak, jasa transportasi juga banyak berhenti bahkan industri kecil pun terdampak dalam situasi global seperti ini. Hal ini dikarenakan adanya penerapan PSBB yang dilakukan pemerintah, yang menyebabkan aktivitas ekonomi dan bisnis di Indonesia ikut terdistraksi.

Pandemi covid-19 yang terjadi di Indonesia mempunyai dampak yang cukup serius dan menimbulkan banyak keresahan di masyarakat. Hal ini dikarenakan masyarakat kehilangan pendapatannya, dimana sebelum adanya pandemi ini, masyarakat dapat menjalankan aktivitas ekonomi dan bisnis secara normal, tetapi setelah adanya covid-19 banyak aturan pembatasan yang dilakukan oleh pemerintah sehingga hal ini menyebabkan rata-rata pendapatan dari masyarakat cenderung menurun atau tidak ada pemasukan yang diterima. Oleh karena itu, apabila dibiarkan terus menerus kondisi perekonomian di Indonesia akan semakin terpuruk dan tingkat kemiskinan di Indonesia akan semakin tinggi. Hal tersebut dibuktikan dengan data BPS (2021) bahwa presentase penduduk miskin Indonesia semester 1 tahun 2019 sebesar 9,41 persen meningkat menjadi 10,19 persen pada semester 2 tahun 2020 .

Dalam momentum ini, Islam sebagai agama mayoritas yang dianut negara Indonesia juga ikut hadir dan berperan dalam upaya penanganan covid-19 yang terjadi di Indonesia. Salah satunya melalui penggunaan instrumen wakaf yang diharapkan mampu berperan secara optimal dalam mengatasi permasalahan sosial dan ekonomi. Sebagaimana fintech yang berperan sebagai penghubung antara kelompok dengan kemampuan finansial tinggi dan kelompok yang mengalami kekurangan dana akibat pandemi covid-19 (Lida 2020), wakaf juga diharapkan dapat berperan dalam mengatasi kekurangan tersebut.

Hal yang sama juga diungkapkan oleh Saputra (2020) melalui instrumen yang berbeda yaitu zakat, di mana hasil penelitiannya menunjukkan bahwa zakat merupakan sarana yang dapat membantu masyarakat yang terdampak virus covid19. Oleh karena itu, wakaf sebagai salah satu instrumen sosial dari implementasi ekonomi syariah dapat mengambil peranannya di tengah adanya pandemi covid19. Hal ini menunjukkan komitmen dalam pengembangan teoritis ekonomi syariah sekaligus praktiknya secara langsung sebagai solusi dalam mengatasi permasalahan kehidupan.

Dalam Islam, upaya-upaya mengatasi permasalahan sosial ini harus mempunyai tujuan yang strategis dan jelas. Adapun dalam Islam, tujuan-tujuan ini disebut tujuan syariah atau yang lebih dikenal dengan maqashid al-syariah. 
Maqashid al-syariah menjelaskan mengenai syariat-syariat yang ditetapkan oleh Allah SWT dalam lima bentuk, sebagaimana menurut Imam Syatibi yaitu hifdzu al-din (konsep perlindungan agama), hifdzu al-nafs (konsep perlindungan jiwa), hifdzu al-aql (konsep perlindungan akal), hifdzu al-mal (konsep perlindungan harta) dan hifdzu al-nasb (konsep perlindungan keturunan). Dengan demikian wakaf yang berpotensi dan bermanfaat ekonomis dalam kepentingan ibadah juga dapat dilakukan untuk menyejahterakan masyarakat. Selain itu, wakaf juga diharapkan dapat mengambil peran dalam penanganan masalah, seperti masalah covid-19 melalui tujuan syariah yang telah ditetapkan.

Penelitian tentang pemanfaatan lembaga keuangan syariah pada masa pandemi covid-19 sudah banyak dilakukan oleh para peneliti seperti Hadi (2017); Amarodin (2019); Faiza (2019); Iskandar, Possumah, and Aqbar (2020); Kadir et al. (2020). Kendati sudah banyak penelitian yang mengeksplorasi tentang pemanfaatan lembaga keuangan syariah pada masa pandemi covid-19, namun belum ada tulisan yang secara khusus mengkaji pendayagunaan instrumen wakaf di tengah pandemi covid-19 dalam perspektif maqashid syariah pada saat ini, sehingga bisa dijadikan celah dalam penelitian.

Tujuan penelitian ini adalah untuk menganalisa apakah bisa wakaf didayagunakan dalam pengalokasiannya untuk mengatasi permasalahan sosial di tengah dampak covid-19. Serta, penanganan tersebut apakah sudah sesuai dengan tujuan syariah, sebagaimana tertuang dalam lima tujuan yang digagas oleh Imam As-Syatibi. Sehingga penelitian ini berupaya untuk mengetahui pendayagunaan wakaf di tengah covid-19 dalam mengatasi permasalahan sosial serta kesesuaiannya pendayagunaan ini dengan perspektif maqashid al-syariah.

\section{TELAAH LITERATUR}

Salah satu topik yang menjadi agenda pembahasan karena sifat dana abadi yang diberikan dan kemaslahatannya dalam lembaga perekonomian syariah adalah wakaf. Menurut Hazami (2016) bahwa harta wakaf yang sudah diberikan sudah bukan menjadi hak milik pribadi melainkan menjadi hak milik umat, sehingga wakaf bisa dijadikan sebagai lembaga ekonomi yang potensial untuk dikembangkan selama dapat dikelola dengan optimal untuk menopang hidup dan harga diri bangsa.

Hadi (2017) dalam tulisannya "pemberdayaan ekonomi melalui wakaf" menjelaskan bahwa wakaf merupakan sumber dana umat yang perlu dikembangkan, didayagunakan dan dikelola secara profesional untuk memperoleh manfaat yang optimal. Salah satu dari pemanfaatan tersebut adalah dengan mendayagunakan wakaf untuk menyejahterakan umat. Lokus penelitian ini adalah mengenai pemberdayaan wakaf secara umum, belum membahas secara khusus pada aspek pemberdayaan yang dilakukan (Hadi 2017).

Amarodin (2019) menjabarkan secara khusus mengenai praktik pemberdayaan wakaf produktif sesuai dengan jenis harta benda wakaf yang dimaksud. Adapun hasil dari pemberdayaan, pengelolaan wakaf dapat membantu membiayai masyarakat yang kurang mampu dan korban bencana alam. Sehingga, kemampuan yang diperoleh bukan hanya keuntungan materi melainkan kemampuan mereka untuk kembali hidup mandiri dan sejahtera. Tulisan ini meskipun telah mengkaji mengenai pemberdayaan wakaf sesuai dengan jenis 
harta bendanya, namun tidak secara langsung menjelaskan mengenai instrumen yang digunakannya.

Dalam lingkup yang lebih khusus, Faiza (2019) menjelaskan dalam penelitiannya mengenai "cash waqf linked sukuk" sebagai pembiayaan pemulihan bencana alam di Indonesia". Instrumen cash waqf linked sukuk (CWLS) merupakan investasi sosial untuk pembiayaan pemulihan bencana alam. Berdasarkan hasil penelitiannya penerapan CWLS mampu mengcover keseluruhan pembiayaan untuk kerusakan dan kerugian pada sektor pemerintah. Bahkan, hasil pengelolaan wakaf dapat menghasilkan manfaat kepada mauquf 'alaih dalam bentuk pembangunan masjid, sekolah maupun pemodalan dengan pembiayaan qard (Faiza 2019).

Senada dengan penelitian Amarodin (2019) dan Faiza (2019) mengenai pemberdayaan wakaf untuk pemulihan bencana alam, Iskandar, Possumah, and Aqbar (2020) menjelaskan bahwa covid-19 dapat dikategorikan sebagai bencana karena salah satunya menimbulkan penurunan (besar) pada fundamental ekonomi riil. Oleh karena itu, peran filantropi Islam dalam keuangan syariah dapat ikut berkontribusi dalam memulihkan guncangan tersebut, salah satunya melalui penguatan wakaf baik berupa wakaf uang, wakaf produktif, cash waqf linked sukuk maupun wakaf untuk infrastruktur.

Darsih Ahmadan dalam tulisannya menjabarkan mengenai aset wakaf dapat diberdayakan untuk membantu penyediaan fasilitas kesehatan di tengah pandemi covid-19, sehingga dana wakaf ini memberikan penyediaan kebutuhan dasar bagi masyarakat. Oleh karena itu, peran lembaga keuangan syariah dapat mengatasi dan memulihkan guncangan ekonomi yang disebabkan oleh wabah covid-19 (Ahmadan 2020). Tulisan ini menjadi landasan teori penelitian penulis tentang pendayagunaan wakaf dalam menghadapi wabah covid- 19 .

Kadir et al. (2020) juga menulis mengenai penggunaan dana zakat sebagai instrumen lain wakaf pada korban covid-19 dalam perspektif maqashid syariah. Hasil penelitiannya menunjukkan bahwa program penyaluran dana sosial untuk penanganan covid-19 seperti zakat sudah sesuai dengan maqashid syariah. Penelitian yang dilakukan Kadir et al. (2020) dapat dilanjutkan dengan menggunakan instrumen yang berbeda yaitu pendayagunaan wakaf di tengah pandemi covid-19 dalam perspektif maqashid al-syariah.

\section{PEMBAHASAN}

\section{Pandemi Covid-19 dan Dampaknya Terhadap Indonesia}

Pada tahun 2020, dunia menghadapi covid-19, virus yang telah menyebabkan kerugian massal dan kepanikan sosial ekonomi di tingkat global (Ceylan, Ozkan, and Mulazimogullari 2020). Dalam merespon hal tersebut, pemerintah Indonesia sudah menyiapkan beberapa alternatif kebijakan, diantaranya dengan memberlakukan aturan pembatasan ketat PSBB bagi masyarakat Indonesia. Pembatasan ini sedikit banyak menghalau pergerakan ekonomi di Indonesia, sehingga yang adalah ketidakpastian ekonomi dan angka pertumbuhan ekonomi tumbuh secara lambat.

Berdasarkan data yang dirilis BPS, ekonomi Indonesia pada triwulan ke II tahun 2020 terhadap triwulan II tahun 2019 mengalami kontraksi pertumbuhan atau minus sebesar 5,32 persen (y-on-y), dan apabila dibandingkan dengan 
triwulan sebelumnya angka pertumbuhan ekonomi minus 4,19 persen (q-to-q) (BPS 2020). Adanya indikasi tersebut meyakinkan bahwa covid-19 telah menghambat laju pertumbuhan ekonomi Indonesia.

Pembatasan aktivitas perkantoran dan industri besar menyebabkan kerugian ekonomi dan mata rantai pasokan pun akan terkena imbasnya, sehingga produksi barang dan jasa pun akan terganggu dengan diberlakukannya kebijakan PSBB (Yamali and Putri 2020). Selain itu, rumah makan, hotel, industri komersil dan tempat pariwisata lainnya juga terdampak serius akibat virus ini, hal ini disebabkan karena menurunnya tingkat mobilisasi yang dilakukan oleh masyarakat karena cenderung memilih berdiam diri di rumah (stay at home).

Beberapa dampak pandemi covid-19 terhadap perekonomian Indonesia diantaranya: (1) Terjadinya gelombang PHK secara besar-besaran yang dilakukan oleh perusahaan, diperoleh data $\geq 1,5$ juta karyawan yang dirumahkan dan diPHK, yaitu dengan perincian 90 persen dirumahkan dan 10 persen di-PHK, hal ini membuat jumlah pengangguran yang ada di Indonesia semakin tinggi. (2) Terjadinya penurunan PMI manufacturing yang mengindikasikan kinerja industri pengolahan, baik dari sisi produksi maupun permintaan, sampai masalah ketenagakerjaan itu memburuk, yaitu pada bulan Agustus 2019 sebesar 49, kemudian turun menjadi 45,3 pada bulan Maret 2020. (3) Terjadinya penurunan pada impor untuk triwulan I-2020 sebesar 3,7 persen (y-on-y). (4) Terjadinya pergerakan inflasi atau peningkatan harga-harga secara umum secara terus menerus pada Maret 2020 yaitu mencapai 2,96 persen (y-on-y). Inflasi tersebut berasal harga emas dengan komoditi pangan. (5) Terjadinya pembatalan 12.703 penerbangan di 15 bandara dalam range Januari-Maret 2020, sehingga menyebabkan adanya indikasi penurunan pendapatan dan kerugian yang cukup besar. (6) Terjadinya penurunan okupansi pada 6 ribu hotel sebesar 50 persen, sehingga hal ini menyebabkan Indonesia kehilangan potensial pendapatannya sebagai salah satu negara dengan sejumlah destinasi yang banyak diminati oleh banyak turis (Hanoatubun 2020).

UMKM juga ikut terkena imbasnya sejak dikeluarkan PP Nomor 21 tahun 2020 tentang pembatasan sosial berskala besar. Hal ini dikarenakan, terbatasnya operasional usaha dan menurunnya konsumen yang berbelanja secara langsung di pasar (Hardilawati 2020). Menurut data Kementrian Koperasi dan Usaha Kecil dan Menengah tahun 2018, jumlah unit usaha UMKM di Indonesia cukup besar yaitu sebesar 64,2 juta (99,9 persen), kontribusinya terhadap tenaga kerja lokal di Indonesia sebesar 117 juta (97 persen) dan kontribusinya terhadap PDB sebesar 8.573.895 Milyar (61,1 persen) (Nainggolan 2020). Sehingga, penurunan pendapatan UMKM sebagai salah satu tulang punggung perekonomian nasional dapat berdampak terhadap kestabilan ekonomi Indonesia.

Salah satu bisnis yang terdampak akibat adanya pandemi covid-19 adalah sektor jasa transportasi online. Pandemi telah menyebabkan kepuasan pelanggan dan keinginan masyarakat untuk kembali menggunakan moda transportasi online menjadi turun. Sebagaimana hasil penelitian Lestari (2020) menunjukkan bahwa terdapat pengaruh kepercayaan dengan kepuasan pelanggan terhadap keinginan masyarakat untuk kembali menggunakan jasa transportasi online di era pandemi covid-19.

Selain pada sektor ekonomi, covid-19 juga telah memberikan dampak yang cukup serius bagi sektor lain. Salah satunya pada kondisi mentalitas 
masyarakat yang terganggu akibat diterapkannya kebijakan PSBB. Sebagaimana penelitian yang dilakukan oleh Wang and Fattore (2020), wabah covid-19 ini telah membahayakan kesehatan mental penduduk di Italia, hal ini dikarenakan dapat meningkatkan kecemasan, stres dan potensi penyakit mental yang semakin tinggi. Bahkan, mereka harus menghadapi tantangan untuk mendapatkan akses ke fasilitas kesehatan, sehingga resiko gangguan mental semakin meningkat. Berdasarkan hasil penelitian, diperkirakan 970 juta orang di seluruh dunia menderita gangguan mental yang meningkat lebih dari 40 persen (Wang and Fattore 2020).

Covid-19 adalah virus yang mengakibatkan terjadinya perubahan pada kondisi tubuh seperti demam, sesak nafas, batuk serta menyerang sistem imunitas tubuh. Coronavirus termasuk dalam keluarga dari virus yang mengakibatkan penyakit ringan, seperti common cold atau pilek dan yang paling berat seperti MERS dan SARS dengan penularan melalui hewan ke manusia (Kemkes 2020). Penyebaran virus corona yang berlangsung di Indonesia mengalami peningkatan yang cukup signifikan. Sejak munculnya covid-19 pada awal bulan Maret hingga 11 Januari 2021, tercatat 836.718 kasus covid-19 yang terjadi di Indonesia. Terdapat 688.739 orang telah dinyatakan sembuh dan 24.343 orang meninggal dunia, sisanya masih menjalani perawatan (Moerti 2021).

Gambar 1 Perkembangan Covid-19 di Indonesia 1-11 Januari 2021

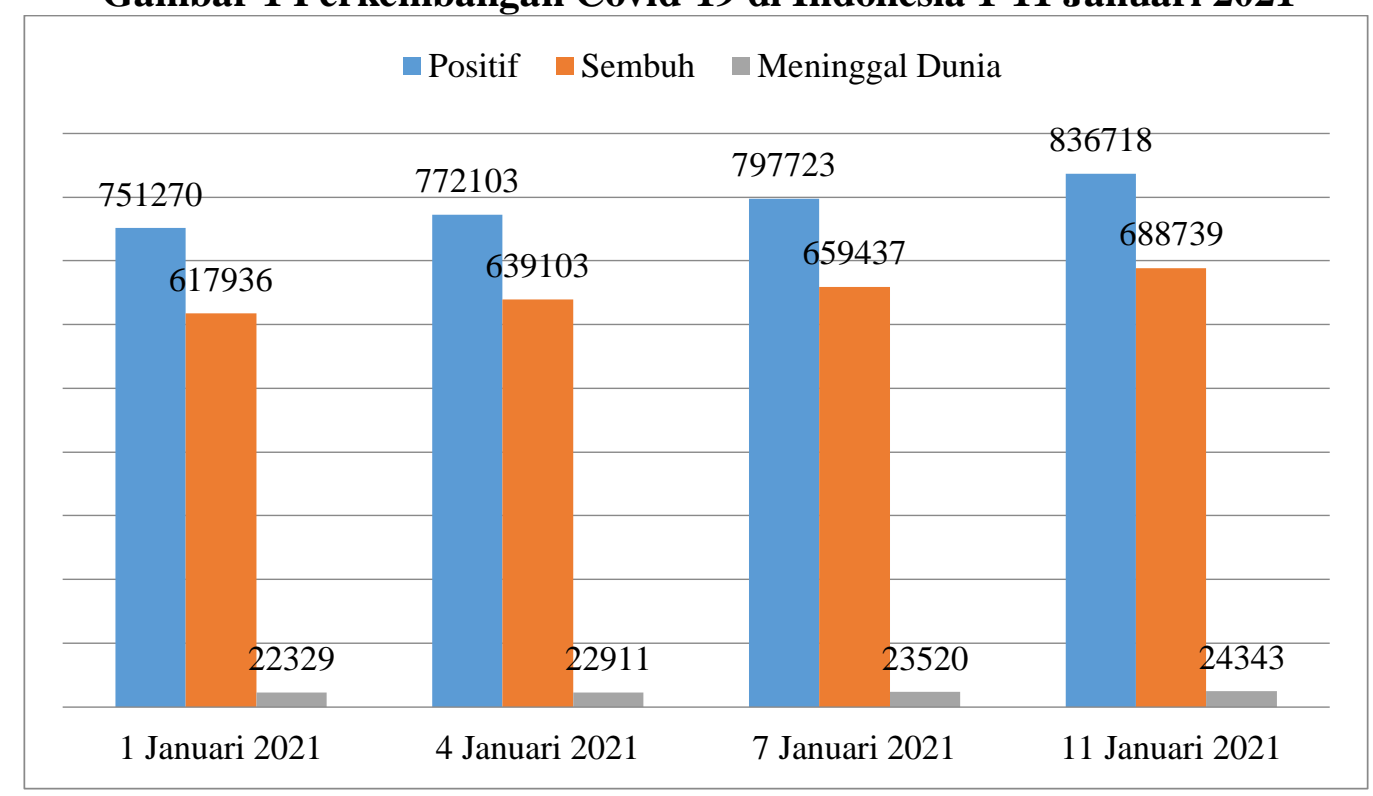

Sumber: data olahan (Moerti 2021)

Dampak yang ditimbulkan covid-19 terhadap ekonomi sangat dirasakan oleh masyarakat. Banyak masyarakat yang kehilangan pekerjaannya, hal ini dikarenakan adanya gelombang PHK besar-besaran yang diterapkan oleh suatu perusahaan, aktivitas jasa transportasi menurun dan banyak pedagang kecil di sekolah-sekolah mangkrak karena work from home (WFH), sehingga pendapatan masyarakat cenderung mengalami penurunan drastis bahkan tidak ada pendapatan sama sekali. Kondisi yang demikian menyebabkan bertambahnya jumlah penduduk miskin yang ada di Indonesia yaitu sebesar 9,78 persen pada Maret 
2020, dimana ini meningkat 0,37 persen poin terhadap persentase tahun sebelumnya (BPS 2020).

Penduduk miskin merupakan kelompok yang sangat rentan terhadap kondisi ini, ditambah mereka kehilangan pekerjaannya. Kelompok ini disinyalir tidak mendapatkan apa-apa dan justru semakin tertekan kondisi perekonomiannya di tengah adanya kebijakan PSBB dan $W F H$.

Tabel 1 Dampak Pandemi Covid-19 terhadap Aktivitas Ekonomi dan Bisnis

\begin{tabular}{ccl} 
No. & Aktivitas Ekonomi & \multicolumn{1}{c}{ Dampak Negatif } \\
\hline 1. UMKM & Menurunkan aktivitas jual beli secara \\
& & secara langsung, dikarenakan distribusi \\
& yang cukup terhambat dan produsen sulit \\
& menjangkau pasar secara offline. \\
& Jasa transportasi mengalami penurunan \\
& yang signifikan, hal ini dikarenakan tingkat \\
& mobilisasi masyarakat di tengah pandemi \\
& ini menurun, masyarakat cenderung \\
& memilih $W F H$ dan stay at home. \\
& Beberapa perusahaan sebelum ada covid- \\
& 19 mempekerjakan karyawan dalam \\
& aktivitas produksinya, sekarang perusahaan \\
& melakukan PHK karyawannya dalam \\
& rangka efisiensi produksi.
\end{tabular}

\section{Pendayagunaan Wakaf di Tengah Pandemi Covid-19 dalam Mengatasi Permasalahan Sosial}

Wakaf dalam bahasa Arab "Waqf” artinya "al-Habs", dimana suatu kata dengan bentuk masdar (infinitife noun) sesuai pokok yang dimaksud yaitu berdiri ataupun berhenti. Apabila pengertian menghentikan ini dihubungkan dengan ilmu tajwid, merupakan tata cara menyebut huruf-huruf, darimana dan bagaimana harus berhenti. Sehingga dalam pengertian ilmu tajwid mengandung arti memberhentikan bacaan. Kemudian juga wakaf diartikan menahan (sesuatu) dengan harta kekayaan (Siah 2010, 17).

Wakaf menjadi suatu instrumen yang sangat potensial untuk dikembangkan umat Muslim, terutama bagi Negara yang dikategorikan sebagai negara berkembang. Di berbagai negara, wakaf sudah banyak dimanfaatkan dalam hal produktif, pengelolaan wakaf ini seharusnya sudah dilakukan sejak awal, sehingga dalam kurun waktu tertentu wakaf bisa dipergunakan untuk memberdayakan umat (K. Lubis 2010).

Adapun peran wakaf bagi agama dan negara yaitu: (1) Wakaf memiliki peranan penting dalam meningkatkan pembangunan ekonomi suatu negara secara menyeluruh, sehingga dapat membantu menyejahterakan umat. Wakaf bisa didayagunakan untuk meningkatkan kemampuan ekonomi umat serta dapat menyediakan sarana pendidikan, kesehatan, tempat ibadah bahkan sebagai penyediaan dalam pembangunan infrastruktur. (2) Sebagai bentuk shadaqah wakaf memiliki potensi dalam memberikan pengaruh terhadap tingkat penawaran secara berkelanjutan, karena wakaf adalah kategori shadaqah yang bisa 
diperuntukkan untuk generasi yang akan datang. (3) Harta yang diwakafkan dapat berpeluang dalam menciptakan lapangan kerja, dimana wakaf dapat digunakan untuk membangun tempat pelatihan ataupun kursus guna meningkatkan kualitas sumber daya manusia (SDM) yang dibutuhkan oleh pasar pada saat ini. Dengan demikian, wakaf dapat berimplikasi pada pertumbuhan sosio ekonomi masyarakat untuk membantu mengurangi kemiskinan dan meningkatkan kesejahteraan.

Pendayagunaan wakaf merupakan suatu aktivitas guna melakukan perencanaan, pelaksanaan dan pengoordinasian pengawasan dalam tujuan untuk mengumpulkan, mendistribusikan dan mendayagunakan wakaf. Kegiatan tersebut telah diatur dalam Undang-Undang Nomor 41 Tahun 2004 tentang Wakaf dan dijalankan oleh Badan Wakaf Indonesia (BWI) (Aziz 2017). Menurut ulama, dana yang diwakafkan diperbolehkan untuk dikelola guna kemaslahatan umat. Kemudian, dalam pengelolaannya, tidak sama dengan pengelolaan zakat ataupun shodaqoh pada umumnya. Pengelola wakaf dapat memelihara harta wakaf secara utuh, namun diusahakan agar dikembangkan sehingga mampu memberi output yang baik dan optimal kepada mauquf alaih.

Akan tetapi, peran wakaf pada saat ini dalam menangani pandemi covid19 dinilai belum optimal apabila dibandingkan dengan instrumen lain. Dana yang disalurkan kepada mereka yang terdampak kebanyakan berasal dari instrumen zakat, infaq dan sedekah (ZIS), sementara dari sektor wakaf masih sangat minim. Hal ini sebagaimana diungkapkan oleh komisioner Badan Wakaf Indonesia (BWI) bidang advokasi dan kelembagaan, Iwan Agustiawan Fuad, "Saat ini banyak lahan wakaf yang belum produktif, sehingga peran wakaf dalam pandemi masih belum maksimal dibandingkan zakat yang memang penyalurannya secara langsung" (Handayani 2020).

Dari aspek syariah, kepentingan wakaf dan zakat ini sudah jelas berbeda, dimana wakaf ini tidak wajib sementara zakat wajib untuk dikeluarkan bagi setiap Muslim yang sudah memiliki harta dan mencapai nishab. Selain itu, hal ini dipengaruhi oleh kurangnya pemahaman masyarakat mengenai wakaf yang masih seputar tanah dan bangunan saja, hal semacam ini dalam pengertian masyarakat masih dianggap tabu karena kurangnya sosialisasi secara luas (Atabik 2014). Dengan demikian, instrumen zakat ini lebih populer dibandingkan wakaf.

Gambar 2 Penggunaan Tanah Wakaf di Indonesia 2021

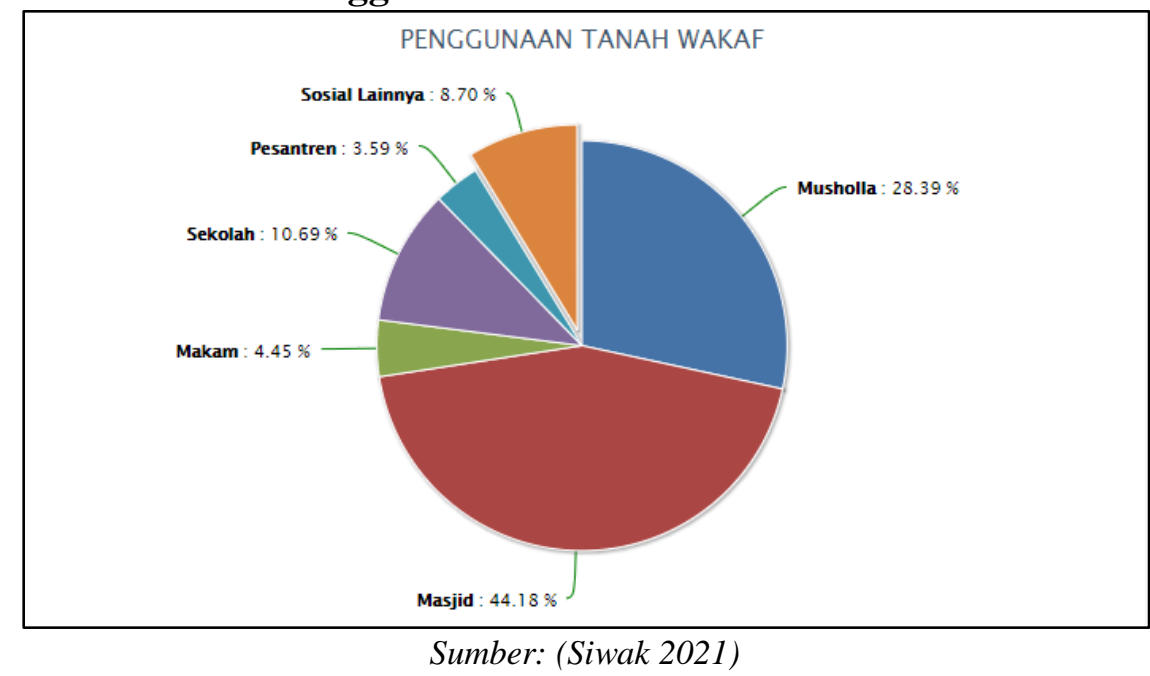


Saat ini banyak sekali lahan wakaf yang belum dikelola secara produktif, padahal pendayagunaan wakaf sangat berpotensi di masa pandemi covid-19. Wakaf bisa menjadi suatu solusi dalam menangani covid-19 melalui instrumen yang digunakannya. Adapun usaha-usaha yang dapat dilakukan melalui potensi wakaf tersebut adalah wakaf dapat dimanfaatkan untuk makam pasien yang meninggal karena covid-19, menyediakan rumah sakit darurat covid-19, kemudian alat untuk melindungi diri (APD) wakaf, rumah sakit untuk ruang isolasi wakaf, pengadaan ventilator wakaf dan lain sebagainya yang dibutuhkan pada saat ini. Pengelolaan wakaf dengan manajemen yang professional, dapat berpeluang untuk dimanfaatkan secara terus-menerus (Hafizah 2021).

Dana wakaf merupakan dana yang digunakan untuk layanan dan kegiatan sosial yang berkelanjutan melalui asset tetap seperti toko, mesin, perdagangan dan lainnya guna mendapatkan pemasukan. Salah satu dana tersebut dapat dimanfaatkan melalui wakaf tunai, yang digunakan sebagai alternatif untuk mengatasi masalah di tengah pandemi covid-19 maupun sesudah pandemi berakhir.

Wakaf di tengah pandemi covid-19 dapat digunakan untuk bantuan modal kerja, renovasi rumah sakit, pendirian puskesmas dan tambahan bantuan permodalan bagi mereka yang terdampak (Nurjannah and Abdullah 2020). Wakaf tunai ini juga merupakan suatu alternatif yang diharapkan dapat mengatasi permasalahan kemiskinan di tengah masyarakat (bagi mereka yang terdampak covid-19), melalui partisipasi aktif dari pihak non pemerintah (masyarakat), khususnya golongan kaya dan memiliki kemauan untuk membantu masyarakat miskin sebagai sesama manusia (Hafizah 2021).

Selain dapat digunakan untuk modal usaha, wakaf tunai juga dapat digunakan secara efektif untuk mendukung banyak kebutuhan warga, sebagaimana fatwa MUI mengenai wakaf tunai (uang) yaitu: (1) Wakaf tunai adalah wakaf yang dilakukan perseorangan, kelompok maupun badan hukum yang berbentuk tunai. (2) Termasuk pula surat-surat berharga. (3) Wakaf yang hukumnya jawaz (boleh), dapat disalurkan dan digunakan untuk hal-hal yang sesuai dengan ketentuan syariah. (4) Nilai pokok wakaf inilah yang harus dijamin kelestariannya untuk tidak boleh dijual, dihibahkan atau bahkan diwariskan (Putra 2020).

Sebagaimana pengertian di atas, maka pendayagunaan wakaf di tengah pandemi sesuai dengan pengertian wakaf tunai yang hukumnya jawaz, karena digunakan untuk penanganan bencana covid-19. Mekanismenya adalah dana wakaf dapat digulirkan pada sektor usaha yang halal dan produktif seperti bisnis online dan terutama pada usaha yang menggunakan online spending, untuk kemudian keuntungan yang diperoleh dapat dimanfaatkan dalam mengatasi pandemi.

Selanjutnya apabila dilihat dari kontribusinya di sektor keuangan, wakaf tunai yang dikelola secara profesional akan memberikan pengaruh yang positif terhadap pengembangan lembaga keuangan Islam, pasalnya sistem bagi hasil yang digunakan oleh lembaga keuangan syariah akan mencegah ketidakmampuan ekonomi karena suku bunga yang tinggi (Nurjannah and Abdullah 2020). 


\section{Pendayagunaan Wakaf dalam Mengatasi Permasalahan Sosial Perspektif Maqashid Al-Syariah}

Dalam pembahasan ini ada hal penting yang perlu ditekankan dan menjadi suatu ulasan dalam Islam yaitu konsep maqashid al-syariah yang mengungkapkan bahwa Islam datang untuk memberikan dan memelihara kemaslahatan bagi umat manusia. Bagi Islam, maqashid syariah menjadi panduan utama dalam praktik keberislaman (Musolli 2018).

Pengertian maqashid syariah sendiri terdiri dua suku kata, yaitu maqashid dan syariah. Dimana kata maqashid berasal dari kata kerja qasada yaqsudu yang memiliki makna seperti tertuju suatu arah, tujuan dan arah yang lurus. Dan pada kata syariah mempunyai arti semua sumber yang asalnya dari al-qur'an dan assunnah yang mutawatir, dimana tidak ada sekalipun campur tangan dan hasil pemikiran manusia.

Menurut pendapat dari As-Syatibi metode atau konsep maqashid syariah terdiri dari tiga konsep kebutuhan yaitu dharuriyah, hajiyah, dan tahsiniyah (Kadir et al. 2020). (1) Konsep dharuriyah adalah kebutuhan yang mendasar (asasi), yaitu semua kebutuhan yang sangat penting dan akan dipenuhi dalam memenuhi kehidupan dan kebutuhan umat. Kebutuhan ini sangatlah diperlukan agar kemaslahatan umat manusia bisa tercapai dengan baik dan sesuai dengan ajaran Islam. Menurut As-Syatibi biasa disebut dengan al-dharuriyah al-khamsah yaitu: perlindungan agama, jiwa, akal, keturunan, dan harta. (2) Konsep hajiyah ini memiliki tujuan agar menjadikan lima unsur tersebut lebih baik lagi dari sebelumnya dan apabila tidak dipenuhi tidak sampai mengancam keselamatan jiwa, akan tetapi mengalami kesulitan dalam memenuhi kebutuhan atau kemaslahatan umat. Sehingga menjadi tantangan tersendiri dalam konsep ini agar bisa dipenuhi dengan baik dan tidak menimbulkan kesulitan. (3) Konsep tahsiniyah ini mempunyai tujuan untuk menyempurnakan dari konsep-konsep sebelumnya agar lebih baik lagi terhadap ulasan-ulasan untuk memelihara lima unsur yang ada dalam maqashid syariah. Dalam konsep ini tahsiniyah tidak terlalu membahayakan atau dengan kata lain tidak begitu berpengaruh apabila konsep ini tidak dilakukan dengan baik.

Apabila dilihat dari potensi wakaf yang ada di Indonesia, pendayagunaan wakaf belum dilakukan secara maksimal untuk meningkatkan perekonomian umat. Dana wakaf sendiri apabila digunakan dan dikelola dengan baik oleh BWI dapat dimanfaatkan untuk kemaslahatan bersama, utamanya di tengah pandemi covid-19 sekarang ini. Karena dana wakaf bisa dikatakan dana yang fleksibel, dimana bisa dipergunakan untuk suatu hal-hal yang lebih bermanfaat dan dapat memberikan manfaat bagi pemberi dan penerimanya.

Namun, pada kenyataannya pendayagunaan wakaf produktif terutama di lahan-lahan wakaf belum digunakan secara optimal atau belum sesuai dengan penggunaannya. Oleh karena itu, peran wakaf untuk menangani pandemi covid-19 dapat dikatakan belum sepenuhnya maksimal dan masih banyak kekurangan dalam penggunaan dana maupun lahan yang digunakan.

Dana wakaf yang dikelola BWI belum semua optimal digunakan dan dialokasikan dengan baik untuk membantu menyelesaikan permasalahan covid19. Meskipun pendayagunaan wakaf ini tidak semuanya menghasilkan output yang diharapkan, tetapi dalam perkembangan Islam sudah terdapat asset wakaf yang digunakan. Salah satu contohnya adalah hasil rumah sakit yang diwakafkan, 
properti yang diwakafkan, tanah wakaf yang digunakan atau dialokasikan untuk tempat pemakaman korban yang terkena covid-19, dan lain-lain.

Dalam penjabaran Imam Syatibi, pada tingkatan pertama terdapat teori dharuriyah, dimana pada masa pandemi ini banyak orang yang sangat membutuhkan bantuan untuk memenuhi kebutuhan hidupnya terutama untuk memenuhi kebutuhan sehari-hari, contohnya pengelolaan atau pendayagunaan dana wakaf yang bisa di alokasikan untuk membantu kemaslahatan manusia dalam memenuhi kebutuhan pokok. BWI di tengah pandemi meluncurkan sebuah gerakan wakaf peduli Indonesia (KALISA) dimana gerakan ini bisa membantu menangani dampak covid-19 dan merupakan perwujudan dari teori maqashid syariah pada tingkatan pertama yaitu dharuriyah, sehingga pendayagunaan wakaf dapat dikelola dengan optimal, berkembang dan tidak asing lagi ditelinga masyarakat Indonesia.

Selanjutnya pada tingkatan kedua dan ketiga, dalam teori maqashid syariah terdapat konsep hajiyah dan konsep tahsiniyah. Konsep hajiyah memiliki tujuan agar kelima unsur tersebut menjadi lebih baik lagi dalam memenuhi kebutuhan. Kebutuhan tersebut apabila tidak dipenuhi tidak sampai mengancam keselamatan jiwanya, tetapi akan mengalami suatu kesulitan. Apabila konsep hajiyah terpenuhi dengan baik, maka akan menyempurnakan tahapan atau konsep yang sebelumnya sehinggga kemaslahatan umat akan tercapai dengan baik.

Pada tingkatan terakhir terdapat konsep tahsiniyah yang mempunyai tujuan untuk menyempurnakan kelima unsur pada teori maqashid syariah. Menurut Subagiyo (2016), bahwa kebutuhan tahsiniyah merupakan kebutuhan tambahan dan pelengkap setelah terpenuhinya kebutuhan ad-dharuriyah dan hajiyah (Aprilianto and Widiastuti 2021). Apabila tingkatan terakhir ini tidak dapat terpenuhi, maka tidak akan memberikan dampak kemusnahan hidup sebagaimana tidak terpenuhinya kebutuhan dharuriyah dan tidak pula membuat kehidupan manusia menjadi sulit sebagaimana tidak terpenuhinya kebutuhan hajiyah. Salah satunya adalah mengenai gaya hidup yang berlebihan, dimana gaya hidup ini tidak relevan dengan akal dan fitrah manusia terutama dari sisi akhlak, sehingga kebutuhan tahsiniyah berusaha menjembatani akhlak manusia dengan gaya hidupnya. Dengan demikian, kebutuhan tahsiniyah ini terkait pada akhlak mulia dan adat yang baik. Adapun penjabaran masing-masing mengenai tinjauan maqashid syariah terhadap pendayagunaan wakaf di tengah pandemi covid-19 dapat dilihat pada Tabel 2.

Tabel 2 Tinjauan Maqashid Al-Syariah Terhadap Pemanfaatan Wakaf di Tengah Pandemi Covid-19

\begin{tabular}{|c|c|c|}
\hline No. & $\begin{array}{c}\text { Maqashid Al- } \\
\text { Syariah }\end{array}$ & Pembahasan \\
\hline 1. & Dharuriyah & $\begin{array}{l}\text { Tujuan bantuan wakaf yang pertama adalah untuk } \\
\text { menjalankan kebutuhan-kebutuhan dasar (dharuriyah) } \\
\text { dalam masa pandemi covid-19. Kebutuhan ini terdiri } \\
\text { dari kebutuhan pangan, bantuan langsung tunai, obat- } \\
\text { obatan untuk menjaga kesehatan, serta bantuan } \\
\text { insentif dana wakaf tunai untuk ketahanan ekonomi } \\
\text { masyarakat. Sebagaimana yang dilakukan oleh BWI } \\
\text { melalui gerakan Wakaf Peduli Indonesia (KALISA), }\end{array}$ \\
\hline
\end{tabular}


2. Hajiyah

dimana wakaf dapat memberikan jaminan hidup bagi masyarakat dengan ekonomi lemah yang terdampak kondisi darurat. Salah satu program donasinya adalah "Lanjutkan Hidup Mereka", dimana hasil investasi wakaf uang akan digunakan untuk dana bantuan tunai orang tua mahasiswa pra-sejahtera yang terdampak sosial ekonomi dari pandemi covid-19. KALISA ini merupakan sebuah program wakaf uang yang penempatannya dilakukan pada instrumen keuangan yang telah dijamin oleh Negara dan Lembaga Penjamin Simpanan (LPS) dengan bagi hasil yang maksimal dan dapat distribusikan kepada masyarakat yang membutuhkan, hal ini dilakukan sebagai sarana pemenuhan dari kebutuhan primer sehingga perlindungan terhadap lima unsur dapat terjamin dengan baik (Humas BWI 2020)

Konsep ini berupaya dalam menghilangkan dan menuntaskan kesulitan melalui pemeliharaan kelima unsur pokok menjadi lebih baik dari sebelumnya. Yaitu dalam hal ini dengan memberikan bantuan fasilitas kesehatan, sehingga biaya kesehatan yang harus dikeluarkan masyarakat menjadi lebih kecil, bahkan bisa dikatakan gratis. Wakaf disini dapat berperan melalui nadzir dengan membangun fasilitas kesehatan seperti rumah sakit, klinik, puskesmas maupun bantuan tenaga medis dalam upaya melindungi masyarakat. Sehingga dengan adanya fasilitas tersebut, masyarakat akan merasa aman dan terlindungi.

3. Tahsiniyah Sementara untuk konsep tahsiniyah ini dimaksudkan supaya manusia dalam menjalani kehidupan sehariharinya dapat melakukan suatu hal yang terbaik dalam upaya pemeliharaan unsur-unsur pokok. Seperti melakukan tindakan preventif. Wakaf dalam hal ini dapat berperan dalam memberikan kebutuhan pelengkap seperti masker, penyediaan sanitasi bersih misalnya dengan memberikan bantuan berupa akses air gratis yang dapat digunakan masyarakat untuk menjaga kebersihannya, sehingga khikmahnya dapat terjaga imunitasnya.

\section{KESIMPULAN}

Kebijakan yang dilakukan pemerintah untuk memutus rantai penularan covid-19 dapat berdampak negatif bagi sisi ekonomi. Penerapan kebijakan PSBB membuat aktivitas ekonomi dan bisnis khususnya di Indonesia terganggu. Peran wakaf pada saat ini untuk menangani pandemi dinilai belum optimal, hal ini dipengaruhi oleh kurangnya pemahaman masyarakat terhadap perkembangan 
wakaf yang ada di Indonesia sehingga hanya mengenal wakaf tanah dan bangunan saja. Meskipun demikian, pendayagunaan wakaf berpotensi dalam membantu mengatasi permasalahan pandemi covid-19, yaitu dengan memberikan bantuan rumah sakit dan fasilitas kesehatan. Kemudian, apabila ditinjau dari perspektif maqashid syariah pendayagunaan wakaf di tengah pandemi covid-19 sudah sesuai dengan tiga konsep kebutuhan yang dijabarkan oleh Imam Syatibi yaitu dharuriyah, hajiyah dan tahsiniyah.

Implikasi dari penelitian ini diharapkan kepada setiap Muslim agar dapat mengetahui bahwa wakaf tidak selalu berhubungan dengan tanah dan bangunan saja. Melainkan wakaf dapat didayagunakan pada sektor produktif lain, seperti halnya wakaf tunai. Instrumen wakaf tunai ini mampu mendorong aktivitas perekonomian ke arah yang lebih maju dan berpotensi dalam mengatasi persoalan sosial-ekonomi di tengah masyarakat. Adapun keterbatasan penelitian ini adalah tidak melakukan penelitian lapangan secara langsung, sehingga tidak dapat melakukan penelaahan secara mendalam mengenai pendayagunaan wakaf di tengah pandemi covid-19. Data pendukung penelitian ini juga masih belum lengkap, terutama mengenai data realisasi penggunaan wakaf.

Diharapkan bagi peneliti selanjutnya untuk dapat mengembangkan studi ini dengan melakukan penelitian lapangan secara langsung. Sehingga dapat diperoleh data rill mengenai penggunaan wakaf di tengah pandemi covid-19 atau bahkan mampu mendeskripsikan masing-masing indikator yang terdapat pada tiap tingkatan maqashid syariah dengan menganalisis secara dalam, sehingga dapat memberikan sumbangsih keilmuan baru.

\section{DAFTAR PUSTAKA}

Ahmadan, Darsih. 2020. "Keuangan Sosial Islam Dalam Menghadapi Wabah Covid-19." Jurnal La Riba: Jurnal Perbankan Syariah 1 (02): 1-15. http://e-jurnal.stitqi.ac.id/index.php/lariba/article/view/50.

Amarodin, Muchamat. 2019. "Optimalisasi Pemberdayaan Wakaf Produktif Di Indonesia (Ikhtiar Strategi Dalam Membengun Kesejahteraan Ekonomi Keumatan).” IKSYAR: Jurnal Ekonomi Syari'ah \& Bisnis Islam 06 (02): 178-90. https://ejournal.staimtulungagung.ac.id/index.php/Eksyar/article/view/403.

Aprilianto, Ersa Dwi, and Tika Widiastuti. 2021. "Pemberdayaan Ekonomi Masyarakat Melalui Pendistribusian Zakat, Infaq Dan Sedekah Pada Masa Pandemi Covid-19 Studi Kasus: LAZISMU Surabaya." Jurnal Ekonomi Syariah Teori Dan Terapan 8 (2): 221-30. https://doi.org/10.20473/vol8iss20212pp221-230.

Atabik, Ahmad. 2014. "Strategi Pendayagunaan Dan Pengelolaan Wakaf Tunai Di Indonesia." ZISWAF: Jurnal Zakat Dan Wakaf 1 (2): 315-35. https://journal.iainkudus.ac.id/index.php/Ziswaf/article/view/1490/.

Aziz, Muhammad. 2017. "Peran Badan Wakaf Indonesia (BWI) Dalam Mengembangkan Prospek Wakaf Uang Di Indonesia." JES (Jurnal Ekonomi Syariah) 2 (1): 35-54. https://doi.org/10.30736/jesa.v2i1.14.

BPS. 2020. "Ekonomi Indonesia Triwulan II 2020 Turun 5,32 Persen." Badan Pusat

Statistik.

2020. 
https://www.bps.go.id/pressrelease/2020/08/05/1737/-ekonomi-indonesiatriwulan-ii-2020-turun-5-32-persen.html.

. 2021. "Persentase Penduduk Miskin Menurut Wilayah (Persen), 20192020." Badan Pusat 2021. https://www.bps.go.id/indicator/23/184/1/persentase-penduduk-miskinmenurut-wilayah.html.

Ceylan, Rahmiye Figen, Burhan Ozkan, and Esra Mulazimogullari. 2020. "Historical Evidence for Economic Effects of COVID-19." The European Journal of Health Economics 21 (6): 817-23. https://doi.org/10.1007/s10198-020-01206-8.

Faiza, Nurlaili Adkhi Rizfa. 2019. "Cash Waqf Linked Sukuk Sebagai Pembiayaan Pemulihan Bencana Alam Di Indonesia." Universitas Islam Negeri Sunan Ampel Surabaya. http://digilib.uinsby.ac.id/33325/.

Hadi, Solikhul. 2017. "Pemberdayaan Ekonomi Melalui Wakaf." ZISWAF: Jurnal Zakat Dan Wakaf 4 (2): 229-44. https://doi.org/10.21043/ziswaf.v4i2.3043.

Hafizah, Gia Dara. 2021. "Peran Ekonomi Dan Keuangan Syariah Pada Masa Pandemi Covid-19." LIKUID: Jurnal Ekonomi Industri Halal 1 (1): 5664. https://journal.uinsgd.ac.id/index.php/likuid/article/view/12733.

Handayani, Rossi. 2020. "Peran Wakaf Belum Optimal Tangani Pandemi Covid 19.” Republika. 2020. https://www.republika.co.id/berita/q9stx3327/peranwakaf-belum-optimal-tangani-pandemi-covid-19.

Hanoatubun, Silpa. 2020. "Dampak Covid-19 Terhadap Prekonomian Indonesia." EduPsyCouns: Journal of Education, Psychology and Counseling 2 (1): 146-53. https://ummaspul.e-journal.id/Edupsycouns/article/view/423.

Hardilawati, Wan laura. 2020. "Strategi Bertahan UMKM Di Tengah Pandemi Covid-19." Jurnal Akuntansi Dan Ekonomika 10 (1): 89-98. https://doi.org/10.37859/jae.v10i1.1934.

Hazami, Bashlul. 2016. "Peran Dan Aplikasi Wakaf Dalam Mewujudkan Kesejahteraan Umat Di Indonesia." Analisis 16 (1): 173-204. http://ejournal.radenintan.ac.id/index.php/analisis/article/view/742.

Humas BWI. 2020. "Wakaf Produktif Bisa Membantu Masyarakat Terdampak Pandemi Covid-19." Badan Wakaf Indonesia. 2020. https://www.bwi.go.id/4806/2020/05/06/wakaf-produktif-bisa-membantumasyarakat-terdampak-pandemi-covid-19/.

Iskandar, Azwar, Bayu Taufiq Possumah, and Khaerul Aqbar. 2020. "Peran Ekonomi Dan Keuangan Sosial Islam Saat Pandemi Covid-19." SALAM: Jurnal Sosial Dan Budaya Syar-I 7 (7): 625-38. https://doi.org/10.15408/sjsbs.v7i7.15544.

K. Lubis, Suhrawardi. 2010. Wakaf Dan Pemberdayaan Umat. Jakarta: Sinar Grafika.

Kadir, Afifuddin, Miftahur Rahman Hakim, Fahmi Syam, and Murdiansah SA. Karim. 2020. "Penggunaan Dana Zakat Pada Korban Covid-19 Perspektif Maqashid Syariah.” Al-Tafaqquh: Journal of Islamic Law 1 (2): 107-16. https://doi.org/10.33096/al-tafaqquh.v1i2.61.

Kemkes. 2020. "FAQ Coronavirus." Kemkes.Go.Id. 2020. https://www.kemkes.go.id/article/view/20030400008/FAQCoronavirus.html. 
Lestari, Indah. 2020. “Analisis Tingkat Kepercayaan Dan Kepuasan Pelanggan Terhadap Niat Untuk Menggunakan Kembali Layanan Transportasi Online Di Era Pandemi Covid-19." Equilibrium: Jurnal Ilmiah Ekonomi, Manajemen Dan Akuntansi 9 (1): 27-35. https://doi.org/10.35906/je001.v9i1.482.

Lida, Puspaningtyas. 2020. "Fintech Syariah Bisa Ambil Peluang Social Crowdfunding." $\quad$ Republika. 2020. https://republika.co.id/berita/q90wt3368/fintech-syariah-bisa-ambilpeluang-emsocial-crowdfunding-em.

Moerti, Wisnoe. 2021. "Data Terkini Covid-19 Di Indonesia Januari 2021." Merdeka.Com. 2021. https://www.merdeka.com/peristiwa/data-terkinicovid-19-di-indonesia-januari-2021.html.

Musolli, Musolli. 2018. "Maqasid Syariah: Kajian Teoritis Dan Aplikatif Pada Isu-Isu Kontemporer." AT-TURAS: Jurnal Studi Keislaman 5 (1): 60-81. https://doi.org/10.33650/at-turas.v5i1.324.

Nainggolan, Edward UP. 2020. "UMKM Bangkit, Ekonomi Indonesia Terungkit." Kemenkeu. 2020. https://www.djkn.kemenkeu.go.id/artikel/baca/13317/UMKM-BangkitEkonomi-Indonesia-Terungkit.html.

Nurjannah, Nurjannah, and M. Wahyuddin Abdullah. 2020. "Cash Waqf: Economic Solution during the Covid-19 Pandemic." FITRAH: Jurnal Kajian Ilmu-Ilmu Keislaman $6 \quad$ (2): 223-42. https://doi.org/10.24952/fitrah.v6i2.3058.

Putra, Husni Amriyanto. 2020. "Wakaf Uang Bisa Menjadi Solusi Ekonomi Saat Pandemi Covid-19." Badan Wakaf Indonesia. 2020. https://www.bwi.go.id/4837/2020/05/19/wakaf-tunai-bisa-menjadi-solusiekonomi-saat-pandemi-covid-19/.

Saputra, Hijrah. 2020. "Zakat Sebagai Sarana Bantuan Bagi Masyarakat Berdampak Covid-19.” Al-Ijtima i: International Journal of Government and Social Science 5 (2): 161-75. https://doi.org/10.22373/jai.v5i2.549.

Siah, Khosyi'ah. 2010. Wakaf Dan Hibah. Bandung: CV. Pustaka Setia.

Siwak. 2021. "Data Tanah Wakaf." Sistem Informasi Wakaf Kementerian Agama. 2021. http://siwak.kemenag.go.id/.

Subagiyo, Rokhmat. 2016. Ekonomi Mikro Islam. Jakarta: Alim's Publishing.

Wang, Yuxi, and Giovanni Fattore. 2020. "The Impact of the Great Economic Crisis on Mental Health Care in Italy." European Journal of Health Economics 21 (8): 1259-72. https://doi.org/10.1007/s10198-020-01204-w.

Yamali, Fakhrul Rozi, and Ririn Noviyanti Putri. 2020. "Dampak Covid-19 Terhadap Ekonomi Indonesia." Ekonomis: Journal of Economics and Business 4 (2): 384-88. https://doi.org/10.33087/ekonomis.v4i2.179. 